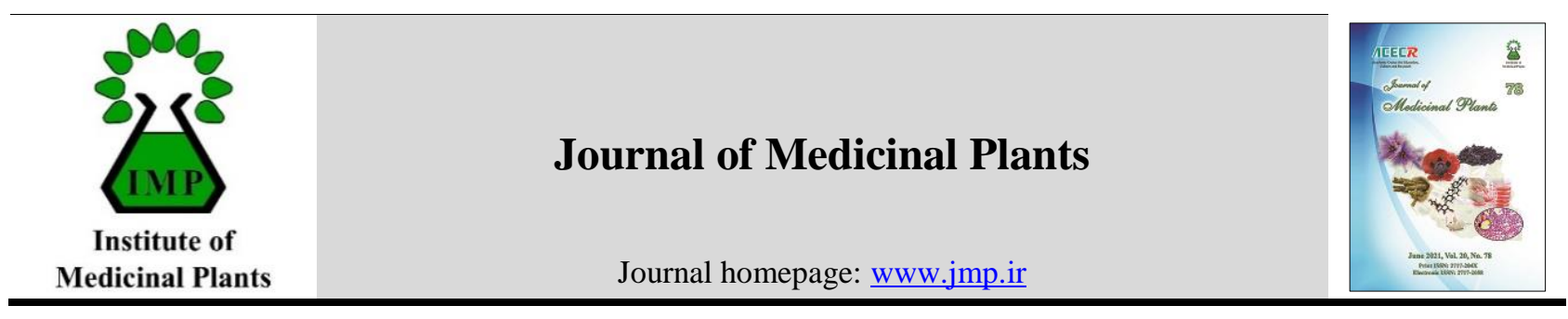

Research Article

\title{
Cytotoxic activity of Centaurea albonitens Turrill aerial parts in colon and breast cancer cell lines
}

\section{Somayeh Esmaeili' ${ }^{1}$, Mahya Asadi ${ }^{2}$, Mahmoud Mosaddegh ${ }^{3}$, Saeed Mohammadi Motamed ${ }^{2}$, Maryam Hamzeloo-Moghadam ${ }^{1}$ *}

${ }^{1}$ Traditional Medicine and Materia Medica Research Center and Department of Traditional Pharmacy, School of Traditional Medicine, Shahid Beheshti University of Medical Sciences, Tehran, Iran

${ }^{2}$ Department of Pharmacognosy, Faculty of Pharmacy and Pharmaceutical Sciences, Tehran Medical Sciences, Islamic Azad University, Tehran, Iran

${ }^{3}$ Department of Pharmacognosy, School of Pharmacy, Shahid Beheshti University of Medical Sciences, Tehran, Iran

\begin{tabular}{|c|c|}
\hline ARTICLE INFO & ABSTRACT \\
\hline Keywords: & Background: Cancer is the second cause of death in developed countries. Colon and \\
\hline Centaurea albonitens & breast cancers are among the most prevalent ones. Research focusing on finding new \\
\hline Cytotoxicity & natural products with fewer side effects to fight cancer is increasing. Objectives: The \\
\hline MTT assay & present study aimed to evaluate the cytotoxicity of Centaurea albonitens Turrill \\
\hline Hoechst 33258 & methanol extract and its fractions against colon and breast cancer cell lines and a normal \\
\hline MCF-7 & cell line of bovine kidney cells. Methods: The methanol extract and petroleum ether, \\
\hline & chloroform and aqueous fractions were provided from the aerial parts of $C$. albonitens \\
\hline & by maceration method in three days. Each day the solvent was refreshed. Colon (HT-29) \\
\hline & and breast (MCF-7) cell lines were treated with the extract/fractions for $48 \mathrm{~h}$ for \\
\hline & $\begin{array}{l}\text { evaluating the cytotoxic activity by MTT assay. The apoptotic induction potential was } \\
\text { also evaluated with the Hoechst } 33258 \text { staining method. Results: The most considerable }\end{array}$ \\
\hline & effect was reported from the chloroform fraction with $\mathrm{IC}_{50}$ values of 25.6 and $25.1 \mu \mathrm{g} / \mathrm{mL}$ \\
\hline & in MCF-7 and HT-29 cells, respectively. In Hoechst staining, condensed chromatin of \\
\hline & the apoptotic cells was observed in both cell lines. Conclusion: Centaurea albonites can \\
\hline & be suggested for further cancer research studies. \\
\hline
\end{tabular}

\section{Introduction}

cancer [1]. Empirical studies suggest that herbal

Nowadays, many research projects are and natural dietary compounds can be introduced focused on finding effective treatments for as cancer inhibitors and plant-derived

Abbreviations: MTT, 3-(4,5-Dimethylthiazol-2-yl)-2,5-diphenyltetrazolium bromide; MCF-7, Breast cancer cell line; HT-29, Human colorectal adenocarcinoma cell line

* Corresponding author: mhmoghadam@sbmu.ac.ir

doi: $10.52547 /$ jmp.20.78.59

Received 4 February 2021; Received in revised form 10 May 2021; Accepted 11 May 2021

(C) 2020. Open access. This article is distributed under the terms of the Creative Commons Attribution-NonCommercial 4.0 International License (https://creativecommons.org/licenses/by-nc/4.0/) 
compounds with antioxidant activity can play a preventive role in cancer. [2]. Treatments such as chemotherapy and radiotherapy cause undesirable side effects [3]; therefore, the use of medicinal plants in the treatment of cancer can be helpful due to their probable fewer side effects. Many species of Centaurea contain sesquiterpene lactones and flavonoids with cytotoxic and antioxidant effects. They have also shown anti-inflammatory and antibacterial properties [4, 5]. Centaurea has about 500 species worldwide and several species of this genus have been introduced for cancer treatment beside their antimicrobial, anti-diabetic and antirheumatic properties [6] due to the presence of sesquiterpene lactones and flavonoids components. Previous studies have shown the cytotoxic effects of C. albonitens (Asteraceae) in acute lymphoblastic leukemia cells while no considerable cytotoxicity was reported in normal cells .The extract of this species, alone and in combination with vincristine, has demonstrated considerable cytotoxicity in NALM-6 (acute lymphoblastic leukemia), REH (acute lymphocytic leukemia), NB4 (acute promyelocytic leukemia) and KMM-1 (myeloma) cell lines [7, 8]. Considering the previous reports about cytotoxic effects of other species of the genus and also the above reported cytotoxicity in some cancerous cell lines, in the present study, we evaluated the cytotoxic effect of $C$. albonitens extracts and fractions in HT-29 and MCF-7 cancer cell lines.

\section{Materials and methods}

\subsection{Plant Collection}

Aerial parts of $C$. albonitens Turrill were collected from Hamadan, Iran. It was authenticated by botanists at Traditional Medicine and Materia Medica Research Center (TMRC) and the herbarium number TMRC 3234 was registered for the voucher specimen.

\subsection{Extraction}

The methanol extract was prepared in three days (plant solvent ratio of 1:10) through the maceration method. Every 24 hours, the extract was filtered and fresh solvent was added. Fractionation was performed by petroleum ether, chloroform and water. The extracts and fractions (except for the aqueous fraction) were condensed using a rotary evaporator. The aqueous fraction was dried by freeze drying method.

\subsection{Cell Lines}

HT-29 (human colorectal adenocarcinoma cell line) and MCF-7 (breast cancer cell line) were provided from the Pasteur Institute of Iran.

\subsection{Evaluation of cytotoxicity by MTT assay}

MTT assay is a colorimetric method based on the transformation of yellow crystals of tetrazolium by succinate dehydrogenase enzyme to insoluble purple formazan crystals. This method has high reliability, accuracy and sensitivity. The amount of color produced is directly related to the number of cells that are metabolically active.

To investigate the cells by MTT assay, HT-29 and MCF-7 cells were seeded with 9000, and 9500 cells/well in 96-well plates, respectively. The plates were kept in the incubator $\left(37^{\circ \mathrm{C}}\right.$ and $5 \% \mathrm{CO}_{2}$ ) for 24 hours. The cells were then treated with serial dilutions of the extracts and fractions for 48 hours. Afterwards, the medium was removed and the cells were exposed to MTT 
solution. Four hours later, the medium was replaced with DMSO. The final color intensity of formazan crystals created by healthy cells was recorded at $570 \mathrm{~nm}$. Tamoxifen was used as the positive control $[9,10]$. The relative cell viability (\%) related to control wells containing cells, cell culture medium and DMSO $1 \%$ was calculated by $[\mathrm{A}]$ samples/[A] control $\times 100$. Where [A] samples is the absorbance of test sample and [A] control is the absorbance of wells containing cells + medium + DMSO, $1 \%$. To calculate $\mathrm{IC}_{50}$ values, viability (\%) versus concentrations was graphed using the Microsoft Excel software.

\subsection{Evaluation of cell nucleus morphology using} Hoechst 33258

Hoechst 33258 can pass through the cell membrane and stain the content of the nucleus of the cell. Since chromatin is condensed in apoptosis, the glowing nucleus of the cells will be detected by fluorescent microscopy.
The cells were cultured in each 96-plates for investigating the induction of apoptosis. The cells were exposed to the extracts/fractions (at the concentration of $\mathrm{IC}_{50}$ from MTT assay). DMSO $1 \%$ served as the negative control. The cells were incubated for 48 hours and then examined [11].

\section{Results}

The petroleum fraction did not dissolve in the medium and was excluded from further analysis. The cytotoxic effect of $C$. albonitens methanol extract and chloroform and aqueous fractions has been shown in Figures 1 and 2. Each test was performed with three repetitions. The $\mathrm{IC}_{50}$ values are presented in Table 1.

Figures 3-6 show cell nucleus morphology by Hoechst33258 staining. As shown in fluorescent microscopy images, dense and shining DNA can be observed in cells treated with chloroform extract (the most effective sample).

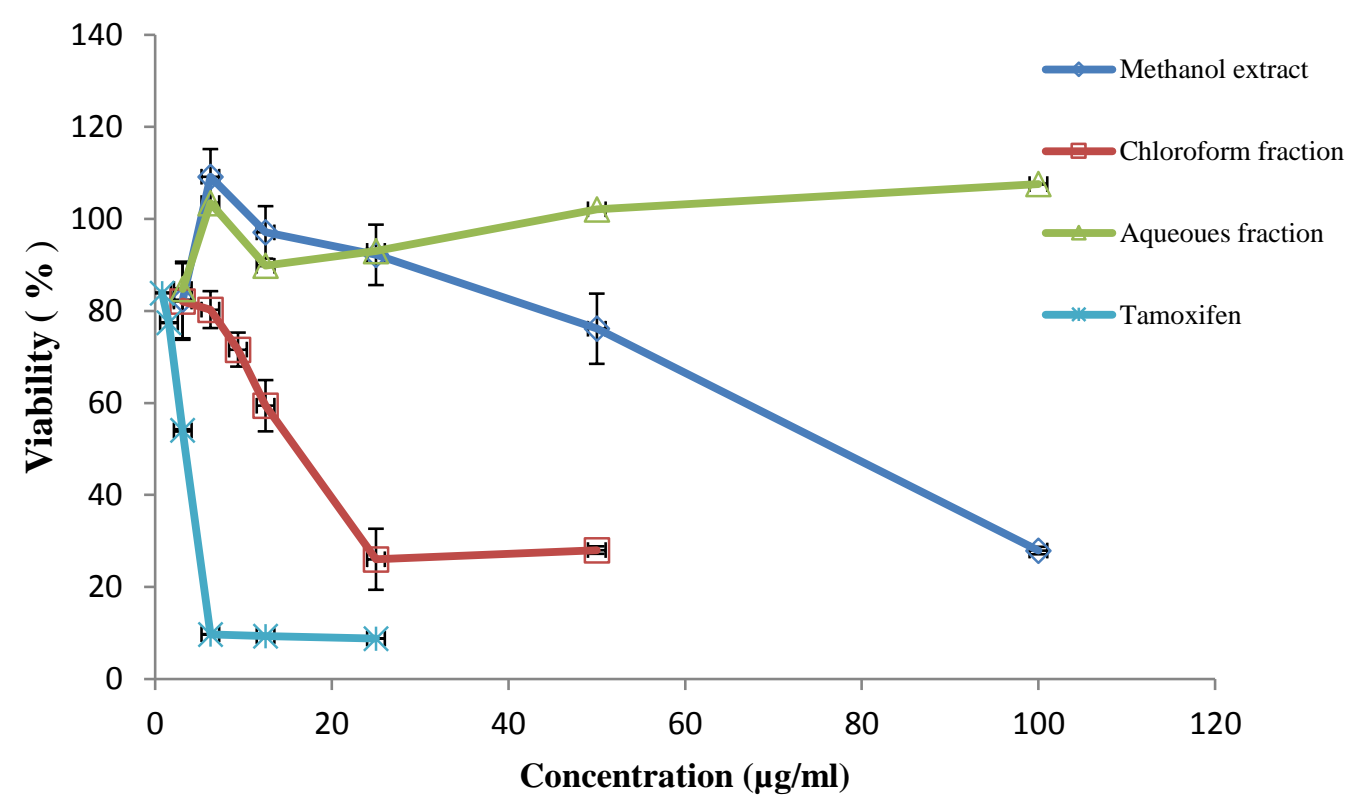

Fig. 1. Cytotoxic effects of C. albonitens extract and fractions in MCF-7 cells 


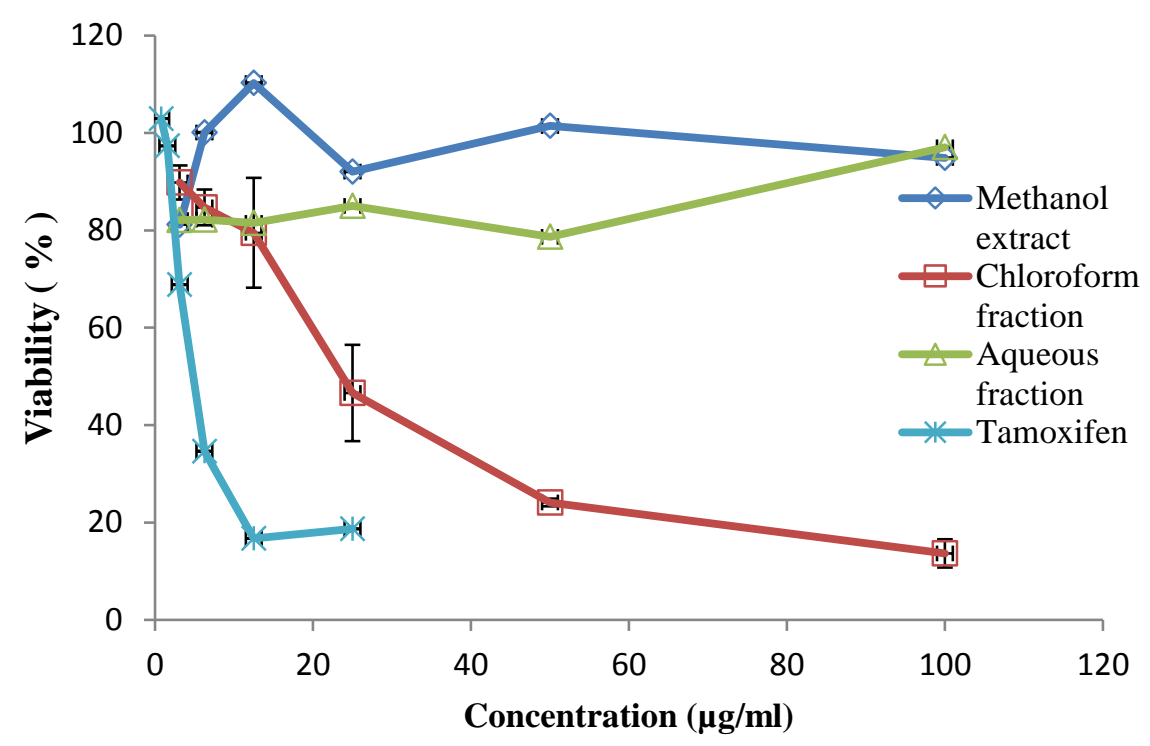

Fig. 2. Cytotoxic effects of C. albonitens extract and fractions in HT-29 cells

Table 1. $\mathrm{IC}_{50}$ values of $C$. albonitens extract and fractions in cell lines

\begin{tabular}{clll}
\hline \multirow{2}{*}{ No. } & Sample & \multicolumn{2}{c}{ IC $_{\mathbf{5 0}} \pm \mathbf{S D}(\boldsymbol{\mu g} / \mathbf{m L})$} \\
\cline { 3 - 4 } & & HT-29 & MCF-7 \\
\hline 1 & Methanol extract & - & $69.6 \pm 5.7$ \\
2 & Petroleum ether fraction & $*$ & $*$ \\
3 & Chloroform fraction & $25.1 \pm 3.9$ & $25.6 \pm 6.6$ \\
4 & Aqueous fraction & - & - \\
5 & Tamoxifen & $4.9 \pm 0.0$ & $4.33 \pm 0.1$ \\
\hline
\end{tabular}

-: Cytotoxic activity was not observed

*: The sample did not dissolve in the medium

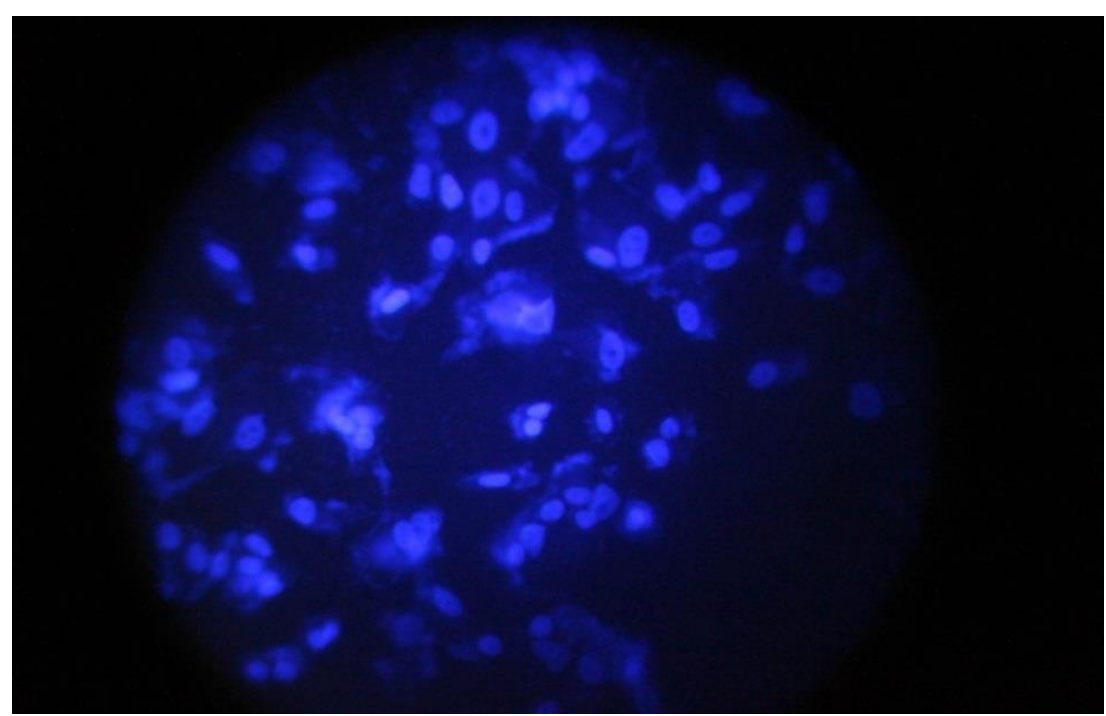

Fig. 3. MCF-7 cells treated with DMSO $1 \%$ as the control 


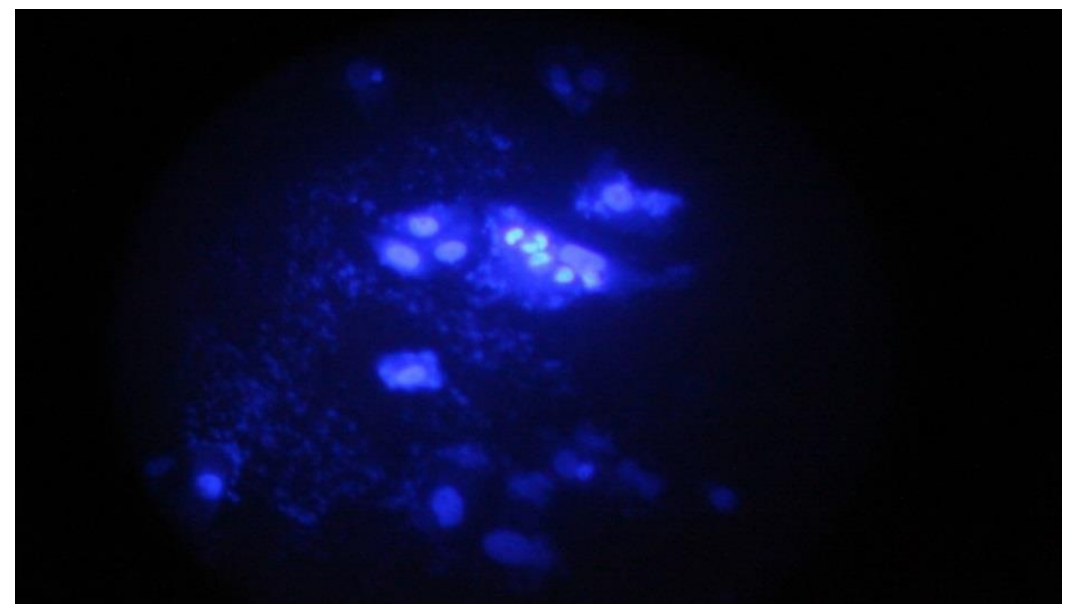

Fig. 4. Change in the morphology of MCF-7 cells treated with $25 \mu \mathrm{g} / \mathrm{mL}$ of $C$. albonitens chloroform fraction

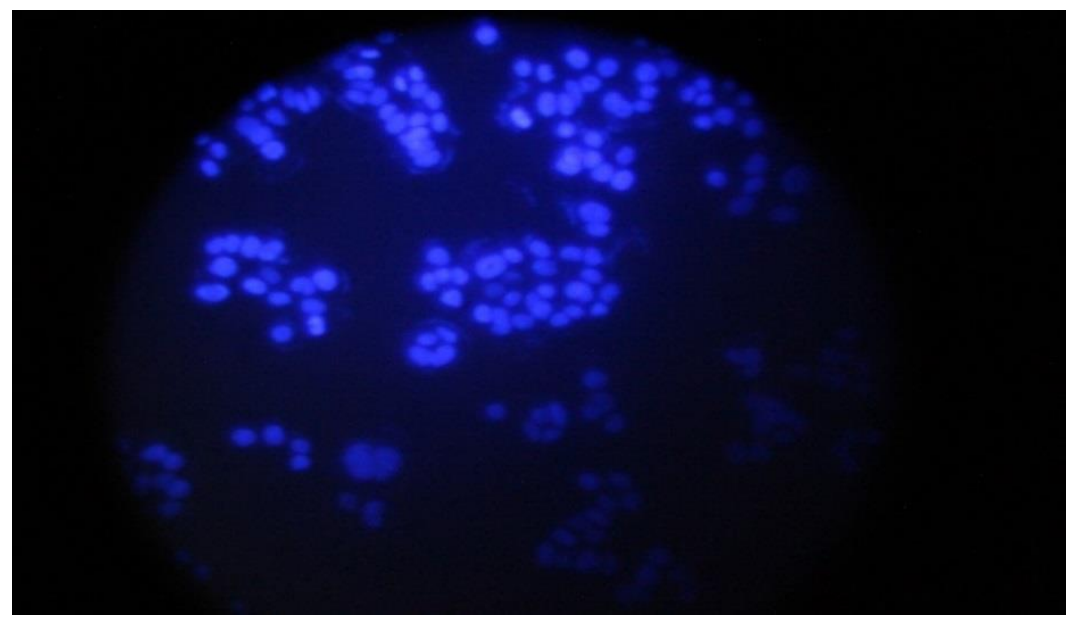

Fig. 5. HT-29 cells treated DMSO $1 \%$ as the control

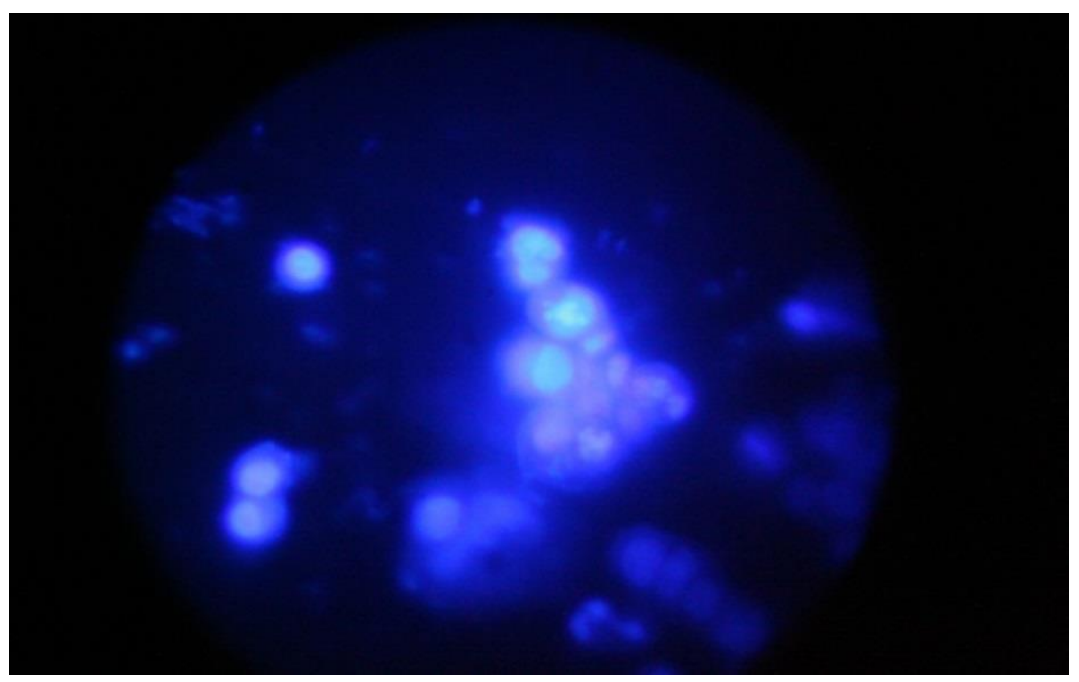

Fig. 6. Change in the morphology of HT-29 cells treated with $25 \mu \mathrm{g} / \mathrm{mL}$ of $C$. albonitens chloroform fraction 


\section{Discussion}

Medicinal plants are valuable sources for developing new drugs in cancer treatment. According to previous reports about the cytotoxic effect of Centaurea species and their potential in cancer research, the cytotoxic effect of Centaurea albonitens, a species with little record of cytotoxic investigation, was evaluated in the present study.

Several cytotoxic research projects have been conducted on other species of Centaurea in different cell lines [12, 13]. Studies about compounds from C. montana [14], cytotoxic and apoptotic effects of $C$. ainetensis in HCT-116 colon cell line and animal model [15], effectiveness of $C$. schischkinii seed extract in colorectal cancer cell line (CaCo-2) [16] and the effects of $C$. bornmuelleri and C. huber-morathii methanol extracts in $\mathrm{CaCo}-2$ cells indicating the cytotoxic effect [17] are some examples.

There are not many studies about the effects of Centaurea species on HT-29 cells; however, researchers have evaluated the effects of different species of Centaurea on MCF-7 cell line some of which have been discussed here. In a study conducted in Turkey, the effect of $C$. kilaea was investigated on three cell lines of Hela (cervical adenocarcinoma), MCF-7 (breast adenocarcinoma) and PC-3 (prostate adenocarcinoma) using MTT assay and the chloroform fraction showed the highest antiproliferation activity in Hela and MCF-7 cells [18]. The ethyl acetate fraction of C. bruguierana led to arrest in the G1 phase of the cell cycle and nuclear fragmentation and induction of apoptosis in MCF-7 cells [19]. A compound from C. cyanus caused subG1 and G1 arrest in the cell cycle of MCF-7 cells. This compound, named
13ASA, was introduced for further investigations in breast cancer studies [20]. Centaurea aegyptiaca also showed cytotoxic activity against MCF-7 cells in MTT assay [21]. The biological effects of $C$. baseri from Turkey were investigated and the extract demonstrated potent selective cytotoxicity in MCF-7 and some other cell lines namely PANC-1, A549, and C6 glioma cells [22].

The results of the present study indicated that the chloroform fraction of $C$. albonitens reduced the viability of both breast cancer (MCF-7) and colon (HT-29) cell lines. The $\mathrm{IC}_{50}$ was 25.0 $\mu \mathrm{g} / \mathrm{mL}$ in MCF-7 cell line and $25.1 \mu \mathrm{g} / \mathrm{mL}$ in HT29 cell line suggesting that the plant can show similar potency for cytotoxicity in both breast and colon cancer cells. Unlike the chloroform fraction, the aqueous fraction did not show cytotoxicity in any of the cell lines. This implies that the observed toxicity may not be attributed to flavonoids because these compounds are polar and should be present in the aqueous fraction. Inactivity of the aqueous fraction and effectivity of the chloroform fraction suggest that semipolar compounds such as sesquiterpene lactones, which are characteristic of the Asteraceae family, can be the effective components in cytotoxic activity. Similar to our study, Ostad et al. evaluated the cytotoxicity of another Centaurea species ( $C$. bruguierana ssp. belangerana) and found the chloroform fraction to be the most potent fraction against colon and breast cancerous cell lines [23]. Chloroform extracts of C. polyclada and $C$. athoa have also shown cytotoxic effects on some cell lines including BT-549, KB and SK-OV-3 [24]. In a bioassay guided isolation study, compounds with different structures including flavone, sesquiterpene and 
lignan-type structures from the chloroform extract of $C$. arenaria were found to be effective against HeLa, MCF7 and A431 cell lines [25]. These results confirm that chloroform fraction of different species of Centaurea contain effective compounds that can induce toxicity. These compounds should be isolated and evaluated in more profound studies.

\section{Conclusion}

In the present study, $C$. albonitens showed the toxic effect on MCF-7 and HT-29 cell lines. Considering that the cytotoxic compounds that have been previously isolated from Centaurea species were mostly sesquiterpene lactones, the observed effects can be somewhat related to these compounds. Isolation and purification of effective constituents may result in active compounds for cancer studies. Also, considering the results of the Hoechst staining, it is necessary

\section{References}

1. Jordan CT, Guzman ML and Noble M. Cancer stem cells. N. Engl. J. Med. 2006; 355(12): 1253-61. doi: 10.1056/NEJMra061808.

2. Hanahan D and Weinberg RA. Hallmarks of cancer: the next generation. Cell. 2011; 144(5): 646-74. doi: 10.1016/ j.cell.2011. 02.013.

3. Dean M. ABC transporters, drug resistance, and cancer stem cells. J. Mammary Gland. Biol. Neoplasia. 2009;14(1):3-9. doi: 10.1007/ s10911-009-9109-9.

4. Safa O, Soltanipoor MA, Rastegar S, Kazemi M, Dehkordi KN and Ghannadi A. An ethnobotanical survey on hormozgan province, Iran. Avicenna. J. Phytomed. 2013; 3(1): 64-81. doi: 10.22038/ajp.2012.12. to investigate the probability of apoptosis and its mechanism in future studies.

\section{Author contributions}

M. M. supervised the study; S. E. and M. HM. conducted the cytotoxicity and apoptosis studies; SM. M. was involved in extraction methods; M. A. performed the experiments.

\section{Acknowledgement}

The present work was based on a Pharm. D thesis (Mahya Asadi). The authors wish to thank the Traditional Medicine and Materia Medica Research Center, Shahid Beheshti University of Medical Sciences for the laboratory support.

\section{Conflicts of interest}

The authors have no competing interests to declare.

5. Tešević $\mathrm{V}$, Milosavljević $\mathrm{S}$, Vajs $\mathrm{V}$, Janaćković P, Đorđević I and Jadranin M. Quantitative analysis of sesquiterpene lactone cnicin in seven Centaurea species wild-growing in Serbia and Montenegro using 1H-NMR spectroscopy. J. Serbian Chem. Soc. 2007; 72(12): 1275-80. doi: 10.2298/JSC0712275T.

6. Khan AN, Fatima I, Khaliq UA, Malik A, Miana GA and Qureshi Z-u-R. Potent antiplatelet constituents from Centaurea iberica. Molecules 2011; 16(3): 2053-64. doi: 10.3390/molecules16032053.

7. Bahmani F, Esmaeili S, Bashash D, Gharehbaghian A. Cytotoxicity of three species of Centaurea genus on acute lymphoblastic 
leukemia cell line (Nalm-6). J. Med. Plants. 2018; 17(66): 156-66.

8. Bahmani F, Esmaeili $S$, Bashash D, Dehghan-Nayeri N, Mashati P, Gharehbaghian

A. Centaurea albonitens extract enhances the therapeutic effects of Vincristine in leukemic cells by inducing apoptosis. Biomed. Pharmacother. 2018; 99: 598-607. doi: 10.1016/j.biopha.2018.01.101.

9. Mosaddegh M, Gharanjik BM, Naghibi F, Esmaeili S, Pirani A, Eslami Tehrani B, Keramatian B and Hassanpour A. A survey of cytotoxic effects of some marine algae in the Chabahar coast of Oman Sea. Res. J. Pharmacogn. 2014; 1(1): 27-31.

10. Esmaeil S, Ghiaee A, Naghibi $F$ and Mosaddegh M. Antiplasmodial activity and cytotoxicity of plants used in traditional medicine of Iran for the treatment of fever. Iran. J. Pharm. Res. 2015; 14: 103-7.

11. Aghaei M, Karami-Tehrani F, Panjehpour M, Salami S and Fallahian F. Adenosine induces cell-cycle arrest and apoptosis in androgen-dependent and independent prostate cancer cell lines, LNcap-FGC-10, DU-145, and PC3. Prostate. 2012; 72(4): 361-375. doi: 10.1002/pros.21438.

12. Koukoulitsa E, Skaltsa H, Karioti A, Demetzos C and Dimas K. Bioactive sesquiterpene lactones from Centaurea species and their cytotoxic/cytostatic activity against human cell lines in vitro. Planta Med. 2002; 68(07): 649-52. doi: 10.1055/s-2002-32893.

13. Shoeb M, Jaspars M, MacManus SM, Celik S, Nahar L and Kong-Thoo-Lin P. Anti-colon cancer potential of phenolic compounds from the aerial parts of Centaurea gigantea (Asteraceae). J. Nat. Med. 2007; 61(2): 164.

Journal of Medicinal Plants
14. Shoeb M, MacManus SM, Jaspars M, Trevidu J, Nahar L and Kong-Thoo-Lin P. Montamine, a unique dimeric indole alkaloid, from the seeds of Centaurea montana (Asteraceae), and its in vitro cytotoxic activity against the $\mathrm{CaCo} 2$ colon cancer cells. Tetrahedron 2006; 62(48): 11172-7. doi: 10.1016/j.tet.2006.09.020.

15. El-Najjar N, Dakdouki S, Darwiche N, ElSabban M, Saliba NA and Gali-Muhtasib H. Anti-colon cancer effects of Salograviolide A isolated from Centaurea ainetensis. Oncol. Rep. 2008; 19(4): 897-904.

16. Shoeb M, Celik S, Jaspars M, Kumarasamy Y, MacManus SM and Nahar L. Isolation, structure elucidation and bioactivity of schischkiniin, a unique indole alkaloid from the seeds of Centaurea schischkinii. Tetrahedron 2005; 61(38): 9001-6. doi: 10.1016/j.tet.2005. 07.047.

17. Sarker SD, Shoeb M, Celik S, Jaspars M, Nahar L and Kong-Thoo-Lin P. Extracts of Centaurea bornmuelleri and Centaurea hubermorathii inhibit the growth of colon cancer cells in vitro. Orient. Pharm. Exp. Med. 2007; 7(4): 336-40. doi: 10.3742/OPEM.2007.7.4. 336.

18. Sen A, Ozbas ST, Akbuga $J$ and Bitis L. In vitro antiproliferative activity of endemic Centaurea kilaea Boiss. against human tumor cell lines. Clin. Exp. Health. Sci. 2015;5(3):149. doi: 10.5455/ musbed. 20150602022750

19. Nasr FA, Shahat AA, Alqahtani AS, Ahmed MZ, Qamar W, Al-Mishari AA and Almoqbil AN. Centaurea bruguierana inhibits cell proliferation, causes cell cycle arrest, and induces apoptosis in human MCF-7 breast 
carcinoma cells. Mol. Biol. Rep. 2020; 47(8): 6043-6051. doi: 10.1007/s11033-020-05679-x. 20. Shahrestanaki MK, Bagheri M, Ghanadian M3, Aghaei M and Jafari SM. Centaurea cyanus extracted 13-O-acetylsolstitialin A decrease $\mathrm{Bax} / \mathrm{Bcl}-2$ ratio and expression of cyclin D1/Cdk-4 to induce apoptosis and cell cycle arrest in MCF-7 and MDA-MB-231 breast cancer cell lines. J. Cell. Biochem. 2019; 120(10): 18309-18319. doi: 10.1002/jcb.29141.

21. Bakr RO, Halim Mohamed SA and Ayoub $\mathrm{N}$. phenolic profile of Centaurea aegyptiaca $\mathrm{L}$. growing in Egypt and its cytotoxic and antiviral activities. Afr. J. Tradit. Complement. Altern. Med. 2016 29; 13(6): 135-143. doi: 10.21010/ajtcam.v13i6.19.

22. Köse YB, Işcan $G$, Göger $F$, Akalın $G$, Demirci $B$ and Başer KHC. Chemical composition and biological activity of Centaurea baseri: new species from Turkey. Chem. Biodivers. 2016; 13(10): 1369-1379. doi: 10.1002/cbdv.201600070.

23. Ostad SN, Rajabi A, Khademi R, Farjadmand F, Eftekhari M, Hadjiakhoondi A,
Khanavi M. Cytotoxic Potential of Centaurea bruguierana ssp. belangerana: the MTT assay. Acta. Med. Iran. 2016; 54(9): 583-89.

24. Sura Baykan Erel, Serdar Demir, Ayse Nalbantsoy, Petek Ballar, Shabana Khan, N. Ulku Karabay Yavasoglu \& Canan Karaalp Bioactivity screening of five Centaurea species and in-vivo anti-inflammatory activity of C. athoa. Pharm. Biol. 2014; 52: 775-81. doi: 10.3109/13880209.2013.868493.

25. Csapi B, Hajdú Z, Zupkó I, Berényi A, Forgo P, Szabó P, Hohmann J. Bioactivityguided isolation of antiproliferative compounds from Centaurea arenaria. Phytother Res. 2010; 24(11): 1664-9. doi: 10.1002/ptr.3187.

How to cite this article: Esmaeili S, Asadi M, Mosaddegh M, Mohammadi Motamed S, Hameloo-Moghadam M. Cytotoxic activity of Centaurea albonitens Turrill aerial parts in colon and breast cancer cell lines. Journal of Medicinal Plants 2021; 20(78): 59-67. doi: $10.52547 / j m p .20 .78 .59$ 
فص-09:

\section{فصلنامه گياهان دارويى}

سميت سلولى قسمتهاى هوايى گياه گل گندم درخشان در ردههاى سلولى سرطانى كولون و پستان

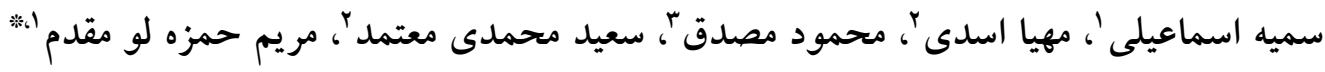

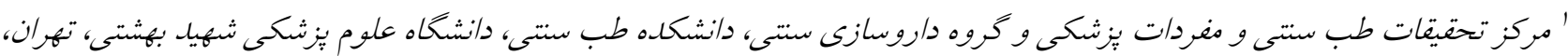

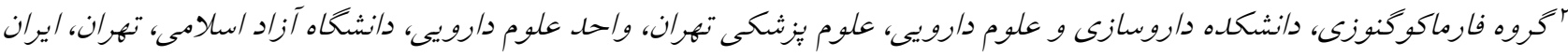

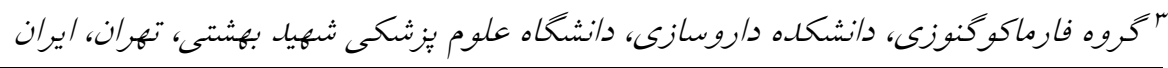

جكيده

مقدمه: سرطان دومين عامل مرگ و مير در كشورهاى توسعهيافته است. از شايعترين سرطانها مىتوان به سرطان يُّان و كولون اشاره نمود. امروزه تحقيقات براى يافتن تركيبات طبيعى با اثرات جانبى كم و همجنين ارزان جهت درمان سرطان رو به افزايش است كه در اين راستا بررسى اثرات سميت سلولى از اولين گامها به شمار مىرود. هدف: در مطالعهى حاضر اثر سميت سلولى عصاره متانولى و فركشنهاى حاصل از آن از گياه گل گندم درخشان با نام علمى (Centaurea albonitens Turrill) بر ردههاى سلولى سرطانى كولون (HT-29)، و بستان مورد بررسى قرارگرفته است. روش بررسى: عصاره متانولى و فركشنهاى يتروليوم اترى، كلروفرمى (MCF-7) و آبى قسمتهاى هوايى گياه، در طى گ روز متوالى به روش ماسراسيون تهيه شدند. هر روز حلال تازه استفاده

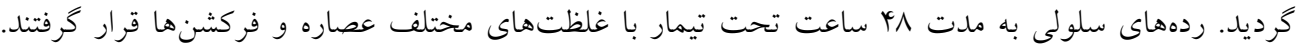
سميت سلولى به روش MTT ارزيابى شد و احتمال القاء آيويتوز توسط رنخَآميزى هوخست مورد بررسى قرار

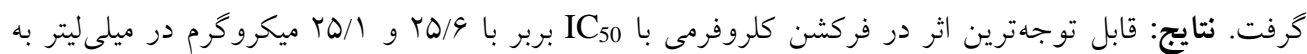
ترتيب در ردهاى سلولى MCF-7 و HT-29 مشاهده شد. در رنخحآميزى هوخست نيز كروماتين متراكم و درخشان در هر دو ردهى سلولى مشاهده شد. نتيجه گيرى: با توجه به اثرات سميت سلولى مشاهده شده در اين مطالعه، گياه فوق كانديد مناسبى جهت ادامه مطالعات در زمينه داروهاى ضدسرطان مىباشد.
اطلاعات مقاله

كالوراثكان:

كل گندم درخشان

سميت سلولى

MTT روش

Hoechst 33258

MCF-7

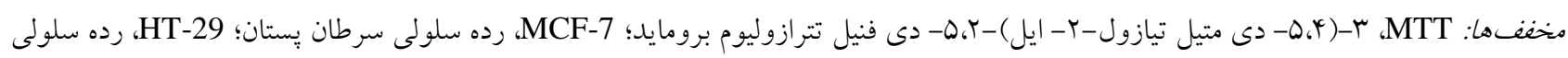
ادنو كارسينوماى كولور كتال انسان mhmoghadam@sbmu.ac.ir نويسنده مسؤول

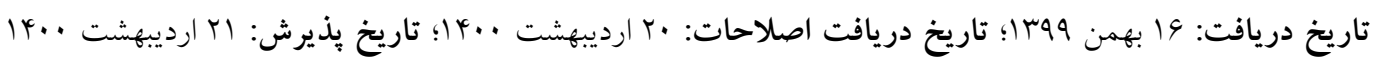
doi: $10.52547 /$ jmp.20.78.59

(C) 2020. Open access. This article is distributed under the terms of the Creative Commons Attribution-NonCommercial 4.0 International License (https://creativecommons.org/licenses/by-nc/4.0/) 